\title{
Yumurtlamanın Son Dönemindeki Yumurtacı Tavukların Rasyonlarına Bor (Ortoborik Asit) Ilavesinin Yumurta Kabuk Kalitesi ve Tibia Biyomekaniği Parametreleri ile Serum, Kabuk ve Tibia Mineral Konsantrasyonları Üzerine Etkisi*
}

\author{
Hacer ARSLAN KAYA ${ }^{1}$, Muhlis MACiT ${ }^{2}$
}

1. Bayburt Üniversitesi, Demirözü Meslek Yüksekokulu, Bayburt, TÜRKiYE.

2. Atatürk Üniversitesi, Ziraat Fakültesi, Zootekni Bölümü, Erzurum, TÜRKiYE.

\begin{tabular}{ccc}
\hline $\begin{array}{c}\text { Geliş Tarihi/Received } \\
\text { 23.05.2017 }\end{array}$ & Kabul Tarihi/Accepted & Yayın Tarihi/Published \\
01.08.2017 & \\
\hline Bu makaleye atıfta bulunmak için/To cite this article: & & \\
Arslan Kaya H, Macit M: Yumurtlamanın Son Dönemindeki Yumurtacı Tavukların Rasyonlarına Bor & (Ortoborik Asit) \\
Illavesinin Yumurta Kabuk Kalitesi ve Tibia Biyomekaniği Parametreleri ile Serum, Kabuk ve Tibia Mineral Konsantrasyonları \\
Üzerine Etkisi. Atatürk Üniversitesi Vet. Bil. Derg., 13 (1): 42-53, 2018. DOI: 10.17094/ataunivbd.315617 \\
\hline
\end{tabular}

Öz: Yumurtacı tavuk rasyonlarına farklı seviyelerde Bor (B) ilavesinin yumurta kabuk kalitesi ve tibia biyomekaniği parametreleri ile serum, kabuk ve tibia mineral konsantrasyonları üzerine etkilerini belirlemek amacıyla yürütülen çalışmada, 62 haftalık Lohman yumurtacı ticari hibrit 0,50, 75 ve $150 \mathrm{mg} / \mathrm{kg}$ seviyelerde B içeren dört farklı rasyonla 12 hafta süreyle yemlenmişlerdir. Rasyona ilave edilen $B$, yumurta ağırlı̆̆ı ve kırılma mukavemetini artırıp $(P<0.05$ ve $P<0.06)$, hasarlı yumurta oranını azaltmış $(P<0.01)$, şekil indeksi ve kabuk kalınlığını etkilememiştir. Rasyona katılan $B^{\prime}$ nin yumurta kabuğu minerallerinden $B, P, C a(P<0.01)$ ve $P b$ seviyesini artırdığı $(P<0.05)$; Fe miktarını düşürdüğü $(P<0.01) ; Z n, M g, M n, N a$ ve $S$ düzeylerini ise etkilemediği $(P>0.05)$ belirlenmiştir. Serum minerallerinden $B$ muameleden etkilenmiş $(P<0.01) ; \mathrm{Cu}, \mathrm{Mn}, \mathrm{Fe}$, $\mathrm{Na}(P<0.01)$ ve $\mathrm{Ca}(\mathrm{P}<0.05)$ azalmış; $\mathrm{Mg}, \mathrm{Zn}$ ve $\mathrm{P}$ ise değişmemiştir. Rasyona ilave edilen $\mathrm{B}^{\prime}$ nin tibia kemiği biyomekanik özelliklerinin tamamına etkisi önemsiz ( $P>0.05)$ olurken, tibia kemik $B$ mineral konsantrasyonunda artış $(P<0.01) ; C a, Z n, M g$, $P$ ve $\mathrm{Mn}$ mineral konsantrasyonlarında azalmaya yol açtığı $(P<0.01)$ tespit edilmiştir. Sonuç olarak, kanatlılarda rasyona $B$ ilavesinin mineral dengesini pozitif yönde etkilediği düşünülerek yumurta kabuk kırılma mukavemetini iyileştirip hasarlı yumurta oranını azaltmak amacıyla yumurtlamanın son dönemindeki yumurtacı tavukların rasyonlarına $50 \mathrm{mg} / \mathrm{kg}$ B ilave edilmesinin yararlı olacağı kanaatine varılmıştır.

Anahtar Kelimeler: Bor, Hasarlı yumurta oranı, Yumurta kabuk kalitesi, Yumurtacı tavuk, Tibia biyomekaniği.

\section{The Effects of Boron (orthoboric acid) Supplementation into Diets of Laying Hens on Egg Shell Quality and Tibia Biomechanic Parameters and Serum, Shell and Tibia Mineral Concentrations During Late Laying Period}

\begin{abstract}
This study was carried out to determine the effects of boron (ortoboric acid) addition into the diets of hens in the late laying period on egg shell quality, and tibia biomechanic parameters and mineral concentrations of serum, egg shell and tibia. Lohman commercial laying hens which are 62 weeks old were fed with 0, 50, 75, and $150 \mathrm{mg} / \mathrm{kg}$ of B for 12 weeks. Although the addition of $B$ into the diet increased the egg weight $(P<0.05)$ and improved the shell strength $(P<0.06)$, and decreased damaged egg rate $(P<0.01)$, the egg shell weight, shape index and shell thickness were not affected by $B$ addition. The addition of $B$ into the diet increased the egg shell minerals such as $B, P, C a(P<0.01)$ and $\mathrm{Pb}(\mathrm{P}<0.05)$; and decreased Fe $(P<0.01) ; \mathrm{Zn}, \mathrm{Mg}, \mathrm{Mn}, \mathrm{Na}$ and $\mathrm{S}$ were not affected by additional $\mathrm{B}(\mathrm{P}>0.05)$. B from serum minerals increased $(P<0.01) ; \mathrm{Cu}$, $\mathrm{Mn}, \mathrm{Fe}, \mathrm{Na}(\mathrm{P}<0.01)$ and $\mathrm{Ca}$ decreased $(P<0.05) ; \mathrm{Mg}, \mathrm{Zn}$ and $\mathrm{P}$ remained unchanged. The effect of $\mathrm{B}$ on the biomechanical properties was not significant $(P>0.05)$, while the $B$ mineral concentration of tibia bone increased $(P<0.01), C a, Z n, M g, P$ and $\mathrm{Mn}$ concentrations decreased $(\mathrm{P}<0.01)$. It is concluded that in order to have a positive effect on egg shell quality traits and damaged egg rate of hens in the late laying period, $50 \mathrm{mg} / \mathrm{kg} \mathrm{B}$ supplementation into the diet is adequate and may be suggested.
\end{abstract}

Keywords: Boron, Damaged egg rate, Egg shell quality, Laying hens, Tibia biomechanics.

\footnotetext{
Wacer ARSLAN KAYA

Bayburt Üniversitesi, Demirözü Meslek Yüksekokulu, Bayburt, TÜRKiYE.

e-posta: hacerkaya@bayburt.edu.tr

*Bu çalışma, 2009/213 proje numarasıyla Atatürk Üniversitesi BAP komisyonu tarafından desteklenen ve Prof. Dr. Muhlis MACiT

danışmanlığında Ziraat Yüsek Müh. Hacer ARSLAN KAYA tarafından hazırlanan Doktora Tezinden özetlenmiştir.
} 
GiRiş

D üşük ve yetersiz yumurta kabuk kalitesi, yumurta üreticilerinin gelirini önemli ölçüde olumsuz etkileyen faktörlerden birisidir. Bu nedenle yumurta kabuğu kalitesini etkileyen faktörler üzerinde çalışılması oldukça önemlidir. Kanatlı endüstrisinde, kırık-çatlak yumurta oranının artması dolayısıyla önemli ekonomik kayıplara neden olan yumurta kabuk kalitesi; genetik, yaş, yumurtlama zamanı, hastalıklar, çevresel faktörler ve beslenme gibi birçok faktöre bağlı olduğu için kabuk kalitesi ile ilgili problemler de çok yönlü olmaktadır.

Yumurtacı tavuklarda bilhassa bacak kemiklerinin sağ|ıkı gelişimi, hayvan sağlığı ve normal yumurta üretimi için son derece önemlidir. Özellikle kafes yetiştiriciliğinde zaman zaman hayvanların ayaklarında görülen problemler (kafes yorgunluğu) bir taraftan normal yumurta üretimini, diğer taraftan da yumurta kabuk kalitesini olumsuz yönde etkilemektedir (1).

Bunun için rasyondaki enerji, protein ve diğer besin maddelerinin dengeli tutulması şartıyla verim artıııı çeşitli yem katkı maddelerinin ve mikro besin elementlerinin rasyona ilave edilmesi son yıllarda sıkça başvurulan bir yöntemdir. Kendileri tek başına bir yem olarak kabul edilmeyen bu maddeler yumurta verimi, yem tüketimi ve yemden yararlanmayı arttırmanın yanında yemin tadını iyileştirme, yemin peletlenmesini kolaylaştırma, yemlerin ve üretilen ürünlerin kalitesini iyileştirme, hayvan ve insanların sağlıklarını koruma, elde edilen ürünün maliyetini düşürme gibi birçok yararlar sağlamaktadır (2).

Türkiye, dünya Bor rezervlerinin önemli bir kısmını sınırları içinde bulundurmaktadır. Stratejik öneme sahip olan B minerali, ham olarak kullanılabildiği gibi genel olarak rafine ve uç ürünlere dönüştürüldükten sonra da kullanılabilmektedir. Bor'un cam endüstrisinden sabun ve deterjanlara, gübre ve tarımsal ilaçlardan aleve dayanıklı malzemelere, elektronik uzay teknolojilerine, tarım ve hayvancılık sektörüne kadar uzanan geniş bir kullanım alanına sahip olduğu bildirilmiştir (3).
Mikro besin elementlerinden biri olan Bor'un (B) bitkiler için esansiyel bir element olduğu uzun zamandan beri bilinmekte ise de insan ve hayvan beslemesinde kullanımı oldukça yeni ve güncel bir konu olup, bu elementin insanlar ve hayvanlar için esansiyel olup olmadığı henüz kesinlik kazanmamıştır. Bununla beraber 1980'li yılların başından itibaren insan ve hayvanlarda yapılan çalışmalarda B'nin esansiyel olabileceğini gösteren bulgular elde edilmesine rağmen biyokimyasal fonksiyonu ya da fonksiyonları henüz tam olarak belirlenmemiştir (4). Bor ile ilgili araştırmaların önemli bir bölümü endüstriyel çalışmalar üzerine olup, hayvan besleme ve insan sağlığına etkilerini inceleyen araştırmalar son yıllarda yapılmaya başlanmıştır (5).

Günümüze kadar konu ile ilgili yapılan çeşitli çalışmalar B'nin, vücutta hayati fonksiyonların yerine getirilmesinde görev yapan enerji sübsratlarının (makro elementler, trigliserid, glukoz gibi) kullanım ve metabolizmalarını etkilediği, beyin, iskelet ve bağışıklık sistemi gibi çeşitli vücut sistemlerinin fonksiyonlarını ve kompozisyonlarını genellikle faydalı yönde değiştirdiği bildirilmiştir. $(6,7,8)$.

Ülkemiz hayvancılığında kanatlı yetiştiriciliği ve buna bağlı olarak kanatlı besleme, et ve yumurta ihtiyacı yönünden öncelikli gelen konulardır. Bu nedenle, söz konusu çalışma ile yumurtacı tavuk yemlerine farklı seviyelerde Bor ilavesinin yumurta kabuk kalitesi ve tibia kemiği biyomekaniği parametreleri ile serum, kabuk ve tibia mineral konsantrasyonları üzerine etkilerinin belirlenmesi amaçlanmıştır.

\section{MATERYAL ve METOT}

Çalışmanın hayvan materyalini, Atatürk Üniversitesi Ziraat Fakültesi Araştırma ve Uygulama Çiftliği Tavukçuluk Şubesi'nde yetiştirilen ve yumurtlamanın üçüncü döneminde bulunan 62 haftalık yaşta Lohman beyaz yumurtacı tavuk; yem materyalini ise özel bir yem fabrikasından temin edilen, bileşimi ve kimyasal kompozisyonu Tablo 1'de verilen yemler oluşturmuştur. 
Tablo 1. Yemin bileşimi ve besin madde kompozisyonu (\%).

Table1. Ingredients and nutrient compositions of basal feed (\%).

\begin{tabular}{lclc}
\hline $\begin{array}{l}\text { Yem Ham } \\
\text { Mad. }\end{array}$ & Bileşim & $\begin{array}{l}\text { Kimyasal } \\
\text { Kompozisyon }\end{array}$ & $\%$ \\
\hline Mısır & 29.90 & Kuru Madde & 88.00 \\
\hline Buğday & 40.00 & Ham Protein & 16.00 \\
\hline $\begin{array}{l}\text { Ayçiçeği } \\
\text { Tohumu K. }\end{array}$ & 4.00 & Ham Selüloz & 7.00 \\
\hline Soya Küspesi & 15.00 & Ham Kül & 13.00 \\
\hline Yağ & 1.00 & $\begin{array}{l}\text { HCL'de } \\
\text { Çözünmeyen kül }\end{array}$ & 1.00 \\
\hline Tuz & 0.30 & NaCl & 0.35 \\
\hline DCP 18 & 1.00 & Lisin & 0.65 \\
\hline $\begin{array}{l}\text { Kalsiyum } \\
\text { Karbonat }\end{array}$ & 8.00 & Metiyonin & 0.32 \\
\hline Premiksler* & 0.20 & Sistin & 0.30 \\
\hline & & Ca & 3.50 \\
\hline & Toplam P & 0.60 \\
\hline & Na & 0.16 \\
\hline & ME/kg yem & 2650 \\
\hline
\end{tabular}

*Her 2 kg'da: 12.000 .000 IU Vitamin A, 2.400.000 IU Vitamin $D_{3}, 30.000$ mg Vitamin E, $4.000 \mathrm{mg}$ Vitamin $\mathrm{K}_{3}, 3.000 \mathrm{mg}$ Vitamin $B_{1}, 7.000 \mathrm{mg}$ Vitamin $B_{2}, 25.000 \mathrm{mg}$ Niasin, 10.000 mg Cal-D-Paln, $5.000 \mathrm{mg}$ Vitamin $B_{6}, 15 \mathrm{mg}$ Vitamin $B_{12}, 45 \mathrm{mg}$ D-Biotin, $1.000 \mathrm{mg}$ Folic Asid, $125.000 \mathrm{mg}$ Cholin Choloride, $2.000 \mathrm{mg}$ Canthaxanthin, $5.00 \mathrm{mg}$ Apo Ester, 50.000 $\mathrm{mg}$ Vitamin C, $80.000 \mathrm{mg}$ Manganez, $60.000 \mathrm{mg}$ Demir (Fe), $60.000 \mathrm{mg}$ Cinko ( $\mathrm{Zn}$ ), 5.000 Kobalt (Co), $1000 \mathrm{mg}$ lyot (I), $150 \mathrm{mg}$ Selenyum (Se) bulunmaktadır.

Bor (düşük sülfatlı borik asit $\mathrm{B}_{2} \mathrm{O}_{3}$ ) bazal rasyonun $\mathrm{kg}^{\prime}$ ına belirlenen oranlarda $(0,5075$ ve 150 $\mathrm{mg} / \mathrm{kg} \mathrm{B}$ ) homojen bir şekilde karıştırılarak muamele gruplarının yemleri hazırlanmıştır. Bor'un rasyona homojen bir şekilde karışımını sağlamak için, önce her bir deneme grubuna ait bir miktar yem ile o grubun rasyonuna katılan B, mikserde iyi bir şekilde karıştırılarak bir ön karma oluşturulmuş, daha sonra bu ön karma Atatürk Üniversitesi Ziraat Fakültesi Yem Ünitesi'nde azar azar rasyona ilave edilmiştir. Yemlerin kimyasal analizleri Atatürk Üniversitesi Ziraat Fakültesi Zootekni Bölümü Yem Analiz Laboratuarı'nda Weende analiz yöntemine göre belirlenmiş (9) ve Tablo 2'de sunulmuştur.

Tablo 2. Karma yemlerin laboratuvar analiz sonuçları. Table 2. Laboratory analysis results of mixed feeds.

\begin{tabular}{lcccc}
\hline Gruplar & Kontrol & $\begin{array}{c}50 \\
\mathrm{mg} / \mathrm{kg} \mathrm{B}\end{array}$ & $\begin{array}{c}75 \\
\mathrm{mg} / \mathrm{kg} \mathrm{B}\end{array}$ & $\begin{array}{c}150 \\
\mathrm{mg} / \mathrm{kg} \mathrm{B}\end{array}$ \\
\hline $\begin{array}{l}\text { Kuru } \\
\text { Madde }\end{array}$ & 88.9 & 89.2 & 89.0 & 88.8 \\
\hline $\begin{array}{l}\text { Ham } \\
\text { Protein }\end{array}$ & 16.2 & 16.4 & 16.0 & 17.1 \\
\hline Ham Yağ & 3.0 & 3.1 & 3.0 & 2.9 \\
\hline Ham Kül & 11.4 & 12.0 & 11.7 & 12.4 \\
\hline ADF & 7.6 & 7.5 & 7.6 & 7.9 \\
\hline NDF & 24.4 & 21.4 & 20.2 & 26.9 \\
\hline ME* & 2650 & 2641 & 2636 & 2640 \\
\hline *Hesaplanarak bulunmuştur & & &
\end{tabular}

Yemlerin mineral element seviyelerinin belirlenmesinde Atatürk Üniversitesi Ziraat Fakültesi Toprak Bölümü Laboratuvarı'nda bulunan Atomik Emüsyon Spektrofotometre cihazı kullanılmıştır (10). Farklı miktarlarda B içeren yemlerin mineral düzeyleri Tablo 3'te sunulmuştur.

Tablo 3. Yemlerin analiz ile belirlenen mineral element seviyeleri.

Table 3. Mineral element levels determined by feed analysis.

\begin{tabular}{|c|c|c|c|c|c|c|}
\hline \multirow{2}{*}{ Mineral } & \multicolumn{4}{|c|}{ Bor Seviyesi (mg/kg) } & \multirow{2}{*}{ Ortalama } & \multirow{2}{*}{$P$} \\
\hline & 0 & 50 & 75 & 150 & & \\
\hline B mg/kg & $2.9 \pm 0.5^{d}$ & $52.8 \pm 2.6^{c}$ & $77.4 \pm 4.7^{b}$ & $150.2 \pm 9.1^{\mathrm{a}}$ & $74.4 \pm 53.7$ & 0.000 \\
\hline Ca mg/g & $51.6 \pm 17.5$ & $49.3 \pm 9.2$ & $43.2 \pm 7.3$ & $43.7 \pm 6.1$ & $47.0 \pm 10.7$ & 0.551 \\
\hline Fe mg/kg & $106.6 \pm 83.4$ & $171.2 \pm 64.9$ & $110.5 \pm 32.9$ & $142.8 \pm 70.03$ & $132.8 \pm 65.9$ & 0.389 \\
\hline $\mathrm{Mg} \mathrm{mg/g}$ & $1.9 \pm 1.9$ & $3.4 \pm 0.4$ & $3.0 \pm 0.2$ & $3.0 \pm 0.2$ & $2.81 \pm 1.1$ & 0.135 \\
\hline $\mathrm{P}$ mg/g & $4.0 \pm 4.3$ & $7.5 \pm 0.8$ & $6.3 \pm 0.5$ & $6.4 \pm 0.4$ & $6.0 \pm 2.4$ & 0.124 \\
\hline Zn mg/g & $0.2 \pm 0.2$ & $0.3 \pm 0.01$ & $0.2 \pm 0.01$ & $0.2 \pm 0.01$ & $0.22 \pm 0.01$ & 0.467 \\
\hline $\mathrm{Mn} \mathrm{mg/kg}$ & $89.9 \pm 75.1$ & $135.2 \pm 13.4$ & $127.6 \pm 23.8$ & $112.6 \pm 11.8$ & $116.3 \pm 41.1$ & 0.334 \\
\hline
\end{tabular}


Deneme gruplarından 1. grup bazal yemle (B1), 2. grup bazal yeme $50 \mathrm{mg} / \mathrm{kg} B$ (B2), 3. grup bazal yeme $75 \mathrm{mg} / \mathrm{kg} \mathrm{B} \mathrm{(B3)} \mathrm{ve} \mathrm{4.} \mathrm{grup} 150 \mathrm{mg} / \mathrm{kg}$ B (B4) ilave edilmiş rasyonlarla beslenmişlerdir. Hayvanlar, alıştırma periyodu (1 hafta) hariç, toplam 12 hafta süreyle beslenmişlerdir. Hayvanlara yem ve su adlibutum olarak verilmiştir. Deneme süresi boyunca 16 saatlik günlük aydınlatma programı flüoresan lamba ile sağlanmıştır. Çalışma tam şansa bağlı deneme planına göre üç katlı batarya tipi kafeslerde, etik kurul ilkelerine uygun olarak gerçekleştirilmiştir.

Farklı B seviyeli grupların yumurta ağırlığı (g), şekil indeksi (\%), kırılma mukavemeti $\left(\mathrm{kg} / \mathrm{cm}^{2}\right)$, kabuk kalınlığı (mm) ve kabuk ağırlığı(g)'nın belirlenmesi için araştırmanın başlangıcından itibaren ayda bir her bir gruptan rastgele 18 yumurta seçilerek oda sıcaklığında 24 saat bekletildikten sonra Atatürk Üniversitesi Ziraat Fakültesi Zootekni Bölümü Laboratuvarı'nda analize tabi tutulmuştur (11).

Deneme periyodunun sonunda yem verilmeden önce her gruptan rastgele 10 hayvan seçilerek, kanat venasından (vena cutenea ulnaris) içinde Lityumheparin bulunan $3 \mathrm{ml}^{\prime}$ lik cam tüplere yaklaşık $2 \mathrm{ml}$ kan alınmıştır. Kan örnekleri Atatürk Üniversitesi Veteriner Fakültesi Biyokimya ABD Laboratuarı'nda $+4^{\circ} \mathrm{C}^{\prime}$ de 5 dakika süre ile $3000 \times \mathrm{G}^{\prime}$ de santrifüj edilerek serum kısmı ayrılmış ve analizler gerçekleştirilinceye kadar $-82^{\circ} \mathrm{C}^{\prime}$ de saklanmıştır. Serum mineral element ( $\mathrm{B}, \mathrm{Ca}, \mathrm{P}, \mathrm{Cu}, \mathrm{Ca}, \mathrm{Mg}$ ve $\mathrm{Zn}$ ) konsantrasyonlarını tespit etmek için örnekler analizden bir gün önce dondurucudan çıkartılarak çözülmeleri için beklenmiştir.

Yumurta kabuğu mineral elementlerinin belirlenmesi için araştırmanın başlangıcından itibaren ayda bir her muamele grubundan rastgele seçilen 4'er adet, üç ayda toplam 48 yumurta kırılıp yumurta kabukları zarlarından ayrılarak analiz edilmek üzere alınmıştır. Deneme sonunda her bir muamele grubuna ait yumurta kabukları gruplara göre birleştirilip havanda dövülerek, her bir muamele grubundan 4'er numune alınarak 0.5 mm'lik elekten geçirildikten sonra $68{ }^{\circ} C^{\prime}$ de 24 saat kurutulmuştur.

Tibia mineral yoğunluğunu tespit etmek için de deneme sonunda her bir gruptan 5 tavuk kesilerek sağ tibia kemiği çıkarılıp, analize kadar -82 o C'de muhafaza edilmiş ve analizden bir gün önce dondurucudan çıkartılarak çözülmeleri için beklenmiştir. Et, yağ ve kemik iliğinden temizlenen 20 adet sağ tibia kemiği, 68 o $C^{\prime}$ de 24 saat kurutulup, havanda dövülerek 0.5 mm'lik elekten geçirilmiştir.

Atatürk Üniversitesi Ziraat Fakültesi Toprak Bölümü Laboratuarı́nda plazmadan $1.0 \mathrm{cc}$ alınırken yumurta kabuğu ve tibia kemiği numunelerinden ise (0.1 mg'a hassas terazide tartılarak) $0.20 \mathrm{~g}$ alınan örneklere $3 \mathrm{cc}$ nitrik asit, 2 cc hidrojen peroksit ilave edildikten sonra 3 farklı adımda (1. adım; 145 o ${ }^{\prime}$ de \%75 mikrodalga gücün de 5 dakika, 2. adım; 180ㄷ' de \%90 mikrodalga gücün de 10 dakika ve 3. adım 100 ㄷ' de $\% 40$ mikrodalga gücün de 10 dakika) 40 bar basınca dayanıklı mikrodalga yaş yakma ünitesinde yakıldıktan sonra serum ve yumurta kabuğu saf su ile 30 cc, tibia kemiği ise 20 cc'ye tamamlanan numunelerde, Atatürk Üniversitesi Ziraat Fakültesi Toprak Bölümü Laboratuarı'nda bulunan Atomik Emüsyon Spektrofotometre cihazı kullanılarak plazma, yumurta kabuğu ve tibia kemiği mineral içerikleri belirlenmiştir (10).

Deneme sonunda tibia kemiklerinin biyomekaniği parametrelerini belirlemek için kesimden 8-10 saat kadar önce aç bırakılan hayvanlardan, deneme sonu tartımında grup ortalamasına en yakın canlı ağırlığa sahip olan hayvanların kesim işlemi Atatürk Üniversitesi Ziraat Fakültesi İşletme Müdürlüğü Tavukçuluk Şubesinin kesimhanesinde yarı otomatik sistemle yapılmıştır. Kanın tamamen süzülmesi için kesimi müteakip yaklaşık 2-3 dk süreyle, hayvanların baş kısımları aşağı olacak şekilde bekletilmiştir. Kesilen hayvanlar 
tüy yolma makinesine atıldıktan sonra her grubu temsilen 10 hayvan olacak şekilde toplam 40 hayvan üzerinden tibia biyomekaniği (20 hayvan) ve tibia mineral konsantrasyonu (20 hayvan) parametreleri incelenmiştir. Bunun için deneme sonunda kan örnekleri alındıktan sonra kesilen hayvanların sağ tibia kemiği çıkarılmıştır. Etlerinden ve yağlarından temizlenen tibia kemikleri poşetlenerek analiz yapılıncaya kadar $-82^{\circ} \mathrm{C}^{\prime}$ de derin dondurucuda muhafaza edilmiş ve analizden bir gün önce dondurucudan çıkartılıp çözdürüldükten sonra yumuşak dokulardan temizlenmiştir.

Kemiklerin biyomekanik özellikleri (kemik çapı, kemik duvar kalınlığı, kemik kesit alanı, kesme kuvveti, kesme gerilmesi ve kesme enerjisi) denemenin sonunda her gruptan kesilen 5 hayvanın taze (kurutulmamış) sağ tibia kemiklerinde tespit edilmiştir.

Tibia kesme kuvveti ve kesme enerjisini tespit etmek için Atatürk Üniversitesi Mühendislik Fakültesi Makine Mühendisliği'nde bulunan İnstron 8872 servohidrolik çeki-bası yorulma ve test cihazında ANSI/ASAE'nin S459 DEC 01 nolu standardına (12) göre hazırlanan bir kalıp kullanılmıştır. Çekme-deney cihazında yükleme hızı dakikada $5 \mathrm{~mm}$ olarak ayarlanmıştır. Kesme kuvveti kemiğin ortasında 15 mm'lik bir kısımda gerçekleştirilmiştir. Kesme kuvvetdeformasyon diyagram verileri ile birlikte bu veriler kullanılarak kemiklerin kesme enerjileri bulunmuştur (13).

\section{İstatistiksel Analiz}

Deneme süresince elde edilen ham veriler (14) paket programı yardımıyla GLM prosedürünün tekrarlamalı gözlem yöntemine göre analize tabi tutulmuştur. Gruplar arası varyans analizinde önemlilik kontrolü için ise Duncan çoklu karşılaştırma testi uygulanmıştır.

\section{BULGULAR}

Yumurtacı tavuk rasyonlarına 0, 50, 75 ve 150 $\mathrm{mg} / \mathrm{kg}$ seviyelerinde B ilavesiyle elde edilen hasarlı yumurta oranı değerleri sırasıyla $4.61 \pm 4.72^{\mathrm{a}}$, $2.45 \pm 3.63^{c}, 3.79 \pm 4.87^{\text {ab }}$ ve $3.29 \pm 3.61^{\text {bc }}$ olup, en düşük hasarlı yumurta oranı \%2.45 ile B2 grubunda, en yüksek hasarlı yumurta oranı ise \%4.61 ile B1(kontrol) grubunda gözlenmiştir. Yumurtacı tavuk rasyonlarına B ilavesinin hasarlı yumurta oranı üzerine etkisi önemli $(P<0.01)$ bulunmuştur.

Yumurta ağırlığı B ilavesinden etkilenmiş $(P<0.05)$ ve en yüksek yumurta ağırlığı $150 \mathrm{mg} / \mathrm{kg} B$ içeren rasyonla beslenen grupta tespit edilmiştir. Gruplar arasında yumurta ağırlıkları bakımından aylara göre meydana gelen farklılıklar da önemli $(P<0.01)$ olmuştur (Tablo 4). Yumurtacl tavuk rasyonlarına B ilavesinin şekil indeksi (\%) üzerine etkisi önemsiz ( $P>0.05)$ olmuştur. Rasyona katılan B'nin kabuk kırılma mukavemeti $\left(\mathrm{kg} / \mathrm{cm}^{2}\right)$, kabuk ağırlığı (g) ve kabuk kalınlığı (mm) üzerine etkileri önemsiz ( $P>0.05$ ) olmasına rağmen başta $50 \mathrm{mg} / \mathrm{kg}$ seviyesi olmak üzere, bütün gruplarda söz konusu parametrelerde rakamsal artış gözlenmiştir. 
Tablo 4. Yumurtacı tavuk rasyonlarına bor ilavesinin yumurta ağırlığı ve yumurta kabuk kalite kriterlerine etkisi. Table 4. Effect of boron supplementation into diets of hens on egg weight and egg shell quality traits.

\begin{tabular}{|c|c|c|c|c|c|}
\hline \multirow[t]{2}{*}{ Gruplar } & \multicolumn{5}{|c|}{ Yumurta Ağırlığı (g) } \\
\hline & 1. ay & 2. ay & 3. ay & Grup Ort. & $P$ \\
\hline B1 & $65.52 \pm 4.40^{c}$ & $64.25 \pm 4.08$ & $65.10 \pm 5.05$ & $64.96 \pm 4.47^{b}$ & \\
\hline B2 & $66.18 \pm 3.65^{b c}$ & $65.31 \pm 3.90$ & $64.24 \pm 4.67$ & $65.24 \pm 4.10^{b}$ & \\
\hline B3 & $68.57 \pm 4.59^{a b}$ & $66.24 \pm 4.81$ & $64.74 \pm 4.33$ & $66.52 \pm 4.77^{a b}$ & \\
\hline B4 & $70.31 \pm 3.75^{a}$ & $67.16 \pm 5.28$ & $64.26 \pm 3.46$ & $67.24 \pm 4.85^{a}$ & \\
\hline Ay Ort. & $67.65 \pm 4.47^{\mathrm{A}}$ & $65.74 \pm 4.59^{\mathrm{B}}$ & $64.58 \pm 4.34^{\mathrm{B}}$ & $65.99 \pm 4.62$ & \multirow{2}{*}{0.000} \\
\hline \multirow[t]{2}{*}{ Grup P } & 0.003 & 0.263 & 0.923 & 0.022 & \\
\hline & \multicolumn{4}{|c|}{ Şekil İndeksi (\%) } & \\
\hline B1 & $75.22 \pm 2.19$ & $75.41 \pm 1.87$ & $75.05 \pm 2.54$ & $75.23 \pm 2.18$ & \\
\hline B2 & $75.72 \pm 2.16$ & $75.06 \pm 2.40$ & $76.22 \pm 2.06$ & $75.67 \pm 2.22$ & \\
\hline B3 & $74.97 \pm 1.73$ & $74.83 \pm 2.81$ & $74.14 \pm 2.44$ & $74.65 \pm 2.36$ & \\
\hline B4 & $75.19 \pm 2.19$ & $75.64 \pm 2.59$ & $75.86 \pm 2.41$ & $75.56 \pm 2.37$ & \\
\hline Ay Ort. & $75.28 \pm 2.05$ & $75.24 \pm 2.41$ & $75.32 \pm 2.46$ & $75.28 \pm 2.30$ & \multirow{2}{*}{0.977} \\
\hline \multirow[t]{2}{*}{ Grup P } & 0.740 & 0.760 & 0.050 & 0.096 & \\
\hline & \multicolumn{4}{|c|}{ Kırılma Mukavemeti $\left(\mathrm{kg} / \mathrm{cm}^{2}\right)$} & \\
\hline B1 & $2.15 \pm 1.07^{a}$ & $1.22 \pm 0.57^{b}$ & $1.36 \pm 0.79$ & $1.58 \pm 0.92$ & \\
\hline B2 & $2.26 \pm 0.87^{a}$ & $1.78 \pm 0.93^{\mathrm{ab}}$ & $2.06 \pm 0.93$ & $2.03 \pm 0.95$ & \\
\hline B3 & $1.85 \pm 1.02^{\mathrm{ab}}$ & $2.16 \pm 1.15^{\mathrm{a}}$ & $1.50 \pm 0.96$ & $1.84 \pm 1.06$ & \\
\hline B4 & $1.24 \pm 0.77^{c}$ & $2.08 \pm 0.90^{\mathrm{a}}$ & $1.72 \pm 1.08$ & $1.68 \pm 0.97$ & \\
\hline Ay Ort. & $1.88 \pm 1.02$ & $1.81 \pm 0.97$ & $1.66 \pm 0.96$ & $1.84 \pm 1.06$ & \multirow{2}{*}{0.372} \\
\hline \multirow[t]{2}{*}{ Grup P } & 0.010 & 0.013 & 0.139 & 0.066 & \\
\hline & \multicolumn{4}{|c|}{ Kabuk Ağırlığı(g) } & \\
\hline B1 & $7.85 \pm 0.62$ & $7.38 \pm 0.65$ & $7.47 \pm 0.82$ & $7.58 \pm 0.72$ & \\
\hline B2 & $7.93 \pm 0.66$ & $7.71 \pm 0.70$ & $7.60 \pm 0.65$ & $7.75 \pm 0.67$ & \\
\hline B3 & $8.14 \pm 0.62$ & $7.75 \pm 0.71$ & $7.54 \pm 0.91$ & $7.81 \pm 0.79$ & \\
\hline B4 & $8.20 \pm 0.57$ & $7.64 \pm 0.88$ & $7.56 \pm 0.72$ & $7.80 \pm 0.77$ & \\
\hline Ay Ort. & $8.03 \pm 0.62^{\mathrm{A}}$ & $7.62 \pm 0.74^{B}$ & $7.54 \pm 0.77^{B}$ & $7.73 \pm 0.74$ & \multirow{2}{*}{0.000} \\
\hline \multirow[t]{2}{*}{ Grup P } & 0.271 & 0.425 & 0.965 & 0.258 & \\
\hline & \multicolumn{4}{|c|}{ Kabuk Kalınlığı (mm) } & \\
\hline B1 & $0.41 \pm 0.04$ & $0.42 \pm 0.04$ & $0.38 \pm 0.04$ & $0.40 \pm 0.05$ & \\
\hline B2 & $0.40 \pm 0.05$ & $0.42 \pm 0.04$ & $0.40 \pm 0.03$ & $0.41 \pm 0.04$ & \\
\hline B3 & $0.42 \pm 0.05$ & $0.40 \pm 0.03$ & $0.36 \pm 0.10$ & $0.39 \pm 0.07$ & \\
\hline B3 & $0.41 \pm 0.04$ & $0.40 \pm 0.04$ & $0.37 \pm 0.05$ & $0.39 \pm 0.05$ & \\
\hline Ay Ort. & $0.41 \pm 0.05^{\mathrm{A}}$ & $0.41 \pm 0.04^{A}$ & $0.37 \pm 0.06^{B}$ & $0.40 \pm 0.05$ & \multirow{2}{*}{0.000} \\
\hline Grup P & 0.610 & 0.449 & 0.284 & 0.565 & \\
\hline
\end{tabular}

A,B,C,D,E: Aynı satırdaki, a,b,c; Aynı sütundaki farklı harfle gösterilen ortalamalar arasındaki fark önemlidir. Değerler, ortalama \pm standart sapma olarak verilmiştir.

Yumurtacı tavuk rasyonlarına farklı seviyelerde $B$ ilavesinin serum mineral elementlerine $(B, C u, C a$,

$\mathrm{Mg}, \mathrm{Mn}, \mathrm{Zn}, \mathrm{Fe}, \mathrm{Na}$ ve P) etkisi Tablo 5'de verilmiştir. 
Tablo 5. Yumurtacı tavuk rasyonlarına bor ilavesinin serum mineral elementlerine etkisi.

Table 5. Effect of boron supplementation into diets of hens on serum mineral elements

\begin{tabular}{|c|c|c|c|c|c|c|}
\hline \multirow{2}{*}{$\begin{array}{l}\text { Mineral } \\
\mathrm{mg} / \mathrm{kg}\end{array}$} & \multicolumn{4}{|c|}{ Gruplar } & \multirow[b]{2}{*}{ Ortalama } & \multirow[b]{2}{*}{$\mathrm{P}$} \\
\hline & B1 & B2 & B3 & B4 & & \\
\hline B & $3.88 \pm 0.6^{c}$ & $4.17 \pm 0.6^{c}$ & $5.57 \pm 0.6^{b}$ & $6.02 \pm 0.9^{a}$ & $4.91 \pm 1.1$ & 0.000 \\
\hline $\mathrm{Cu}$ & $1.54 \pm 0.4^{\mathrm{a}}$ & $1.78 \pm 0.3^{a}$ & $0.88 \pm 0.2^{\mathrm{b}}$ & $0.96 \pm 0.2^{b}$ & $1.29 \pm 0.5$ & 0.000 \\
\hline $\mathrm{Ca}$ & $123.46 \pm 20.8^{a}$ & $117.19 \pm 6.9^{\mathrm{a}}$ & $112.51 \pm 8.9^{b}$ & $106.46 \pm 12.8^{b}$ & $114.93 \pm 15.7$ & 0.046 \\
\hline $\mathrm{Mg}$ & $9.91 \pm 2.0$ & $12.84 \pm 4.7$ & $12.03 \pm 3.0$ & $10.36 \pm 1.6$ & $11.27 \pm 3.1$ & 0.414 \\
\hline $\mathrm{Mn}$ & $1.27 \pm 0.32^{\mathrm{ab}}$ & $1.42 \pm 0.40^{\mathrm{a}}$ & $0.90 \pm 0.12^{\mathrm{bc}}$ & $0.72 \pm 0.11^{c}$ & $1.08 \pm 0.38$ & 0.003 \\
\hline $\mathrm{Zn}$ & $16.83 \pm 2.5$ & $17.60 \pm 1.5$ & $16.86 \pm 2.2$ & $16.18 \pm 2.1$ & $16.87 \pm 2.0$ & 0.768 \\
\hline $\mathrm{Fe}$ & $23.43 \pm 4.1^{\mathrm{a}}$ & $14.23 \pm 4.9^{b}$ & $14.44 \pm 3.7^{b}$ & $10.38 \pm 1.7^{b}$ & $15.62 \pm 6.0$ & 0.000 \\
\hline $\mathrm{Na}$ & $5.95 \pm 0.7^{\mathrm{ab}}$ & $6.42 \pm 1.4^{\mathrm{a}}$ & $4.81 \pm 1.1^{\mathrm{b}}$ & $3.46 \pm 0.5^{c}$ & $5.16 \pm 1.5$ & 0.001 \\
\hline$P$ & $65.21 \pm 13.6$ & $56.02 \pm 11.6$ & $49.38 \pm 9.50$ & $47.90 \pm 5.80$ & $54.63 \pm 12.0$ & 0.074 \\
\hline
\end{tabular}

Yumurtacı tavuk rasyonlarına farklı seviyelerde $\mathrm{B}$ ilavesinin etkisi, serum $\mathrm{B}, \mathrm{Cu}, \mathrm{Fe}, \mathrm{Mn}$ ve $\mathrm{Na}$ düzeylerine çok önemli $(P<0.01)$; Ca düzeyine önemli $(P<0.05)$; serum $\mathrm{Mg}, \mathrm{P}$ ve $\mathrm{Zn}$ düzeylerine ise önemsiz olmuştur $(P>0.05)$. En düşük serum $B$ düzeyi 3.88 $\mathrm{mg} / \mathrm{kg}$ ile B1 grubunda, en yüksek serum $B$ düzeyi ise $6.02 \mathrm{mg} / \mathrm{kg}$ ile $150 \mathrm{mg} / \mathrm{kg}$ B ilave edilmiş rasyonla beslenen grupta olmuştur. Bazal rasyona B ilavesiyle serum B düzeyi doğrusal olarak yükselerek önemli derecede $\operatorname{artmış}(\mathrm{P}<0.01), \mathrm{Cu}, \mathrm{Na}, \mathrm{Fe}, \mathrm{Mn}$ ve $\mathrm{Ca}$ düzeyleri ise azalmıştır $(P<0.01$ ve $P<0.05)$.

Yumurtacı tavuk rasyonlarına farklı seviyelerde $B$ ilavesinin yumurta kabuğu mineral elementlerine etkisi Tablo 6'da verilmiştir.

Tablo 6. Yumurtacı tavuk rasyonlarına bor ilavesinin yumurta kabuk mineral konsantrasyonuna etkisi.

Table 6. Effect of boron supplementation into diets of hens on egg shell mineral concentration.

\begin{tabular}{|c|c|c|c|c|c|c|}
\hline \multirow{2}{*}{ Mineral Konsant. } & \multicolumn{4}{|c|}{ Gruplar } & \multirow[b]{2}{*}{ Ortalama } & \multirow[b]{2}{*}{$P$} \\
\hline & B1 & B2 & B3 & B4 & & \\
\hline $\mathrm{B} \mathrm{mg} / \mathrm{kg}$ & $114.9 \pm 39.7^{b c}$ & $99.0 \pm 23.7^{c}$ & $154.8 \pm 28.7^{\mathrm{ab}}$ & $166.93 \pm 8.48^{a}$ & $133.9 \pm 37.9$ & 0.000 \\
\hline Ca mg/g & $522.8 \pm 17.4^{b}$ & $556.2 \pm 15.6^{b}$ & $605.0 \pm 25.1^{\mathrm{a}}$ & $618.1 \pm 34.7^{a}$ & $575.5 \pm 45.1$ & 0.000 \\
\hline Fe $\mathrm{mg} / \mathrm{kg}$ & $92.0 \pm 49.6^{a}$ & $127.5 \pm 11.5^{\mathrm{a}}$ & $96.5 \pm 15.2^{\mathrm{a}}$ & $48.5 \pm 1.91^{b}$ & $91.1 \pm 37.6$ & 0.000 \\
\hline $\mathrm{P} \mathrm{mg} / \mathrm{g}$ & $6.29 \pm 1.1^{\mathrm{ab}}$ & $5.26 \pm 0.32^{\mathrm{b}}$ & $6.81 \pm 0.76^{a}$ & $6.01 \pm 0.50^{\mathrm{ab}}$ & $6.09 \pm 0.88$ & 0.003 \\
\hline Zn mg/kg & $87.0 \pm 16.7$ & $78.0 \pm 23.9$ & $104.8 \pm 14.7$ & $68.8 \pm 5.9$ & $84.6 \pm 20.2$ & 0.052 \\
\hline $\mathrm{Mg} \mathrm{mg/g}$ & $17.00 \pm 2.68$ & $20.50 \pm 5.15$ & $20.07 \pm 2.24$ & $16.46 \pm 0.87$ & $18.51 \pm 3.37$ & 0.211 \\
\hline $\mathrm{Mn} \mathrm{mg/kg}$ & $11.53 \pm 7.11$ & $8.46 \pm 1.52$ & $10.21 \pm 2.03$ & $13.35 \pm 0.85$ & $10.88 \pm 2.87$ & 0.356 \\
\hline $\mathrm{Na} \mathrm{mg/g}$ & $12.94 \pm 1.42$ & $12.83 \pm 2.24$ & $13.91 \pm 2.31$ & $12.77 \pm 1.06$ & $13.12 \pm 1.71$ & 0.797 \\
\hline $\mathrm{Pb} \mathrm{mg} / \mathrm{kg}$ & $3.34 \pm 0.78^{b}$ & $3.15 \pm 0.64^{b}$ & $4.49 \pm 0.73^{a}$ & $3.56 \pm 0.14^{\mathrm{ab}}$ & $3.64 \pm 0.77$ & 0.047 \\
\hline $\mathrm{S} \mathrm{mg} / \mathrm{g}$ & $5.56 \pm 0.49$ & $5.74 \pm 1.19$ & $6.05 \pm 0.60$ & $5.32 \pm 0.17$ & $5.67 \pm 0.70$ & 0.552 \\
\hline
\end{tabular}

Yumurtacı tavuk rasyonlarına farklı seviyelerde B ilavesinin yumurta kabuk mineral elementlerinden $\mathrm{Zn}, \mathrm{Mg}, \mathrm{Na}, \mathrm{Mn}$ ve S üzerine etkisi önemsiz $(P>0.05)$; $B, C a$, Fe ve $P$ ile $P b^{\prime}$ ye ise önemli $(P<0.01 ; P<0.05)$ bulunmuştur. Rasyona B ilavesi yumurta kabuğu B ve Ca miktarını artırmış, Fe miktarını ise azaltmıştır.
Yumurta kabuğu $P$ ve $P b$ düzeyi $75 \mathrm{mg} / \mathrm{kg}$ B ilaveli rasyonla beslenen grupta diğer gruplardan daha yüksek $(P<0.01)$ bulunmuştur.

Yumurtacı tavuk rasyonlarına farklı seviyelerde B ilavesinin kemiğin biyomekanik özelliklerine etkisi Tablo 7'de verilmiştir. 
Table 7. Yumurtacı tavuk rasyonlarına bor ilavesinin tibia biyomekaniği özelliklerine etkisi.

Table 7. Effect of boron supplementation into diets of hens on tibia biomechanic parameters.

\begin{tabular}{|c|c|c|c|c|c|c|}
\hline \multicolumn{7}{|c|}{ Gruplar } \\
\hline Biyomekanik Özellikler & B1 & B2 & B3 & B4 & Ortalama & $\mathrm{P}$ \\
\hline Kemik Çapı (mm) & $5.90 \pm 0.21$ & $5.95 \pm 0.06$ & $5.76 \pm 0.11$ & $5.74 \pm 0.17$ & $5.83 \pm 0.72$ & 0.689 \\
\hline Duvar Kalınlığı (mm) & $0.31 \pm 0.02$ & $0.27 \pm 0.01$ & $0.28 \pm 0.01$ & $0.28 \pm 0.02$ & $0.28 \pm 0.08$ & 0.261 \\
\hline Boşluk Çapı (mm) & $5.28 \pm 0.19$ & $5.41 \pm 0.04$ & $5.20 \pm 0.12$ & $5.18 \pm 0.15$ & $5.27 \pm 0.68$ & 0.615 \\
\hline Kesit Alanı (mm²) & $20.45 \pm 1.4$ & $20.49 \pm 0.4$ & $19.30 \pm 0.6$ & $19.21 \pm 1.1$ & $19.83 \pm 0.48$ & 0.702 \\
\hline Kesme Kuvveti (N) & $562.43 \pm 40.2$ & $510.65 \pm 8.6$ & $466.31 \pm 41.9$ & $481.64 \pm 24.7$ & $505.26 \pm 16.9$ & 0.194 \\
\hline Kemik Stres $\left(\mathrm{N} / \mathrm{mm}^{2}\right)$ & $28.06 \pm 2.78$ & $24.30 \pm 0.76$ & $24.11 \pm 1.84$ & $25.20 \pm 0.98$ & $25.42 \pm 0.89$ & 0.398 \\
\hline KesmeEnerjisi (N.mm) & $661.63 \pm 80.5$ & $638.69 \pm 106.1$ & $555.62 \pm 79.5$ & $542.28 \pm 100.7$ & $599.55 \pm 44.0$ & 0.712 \\
\hline
\end{tabular}

Yumurtacı tavuk rasyonlarına farklı seviyelerde ilave edilen B'nin kemiğin biyomekanik özelliklerinin tümüne etkisi önemsiz olmuştur ( $P>0.05)$.
Yumurtacı tavuk rasyonlarına farklı seviyelerde B ilavesinin tibia mineral elementlerine etkisi Tablo 8 'de verilmiştir.

Table 8. Yumurtacı tavuk rasyonlarına bor ilavesinin tibia mineral elementlerine etkisi.

Table 8. Effect of boron supplementation into diets of hens on tibia mineral elements.

\begin{tabular}{lcccccc}
\hline \multirow{2}{*}{ Mineral Konsant. } & \multicolumn{7}{c}{ Gruplar } \\
\cline { 2 - 7 } & $1.46 \pm 0.94^{\mathrm{b}}$ & $1.86 \pm 0.62^{\mathrm{b}}$ & $5.20 \pm 1.05^{\mathrm{a}}$ & $6.26 \pm 2.12^{\mathrm{a}}$ & $3.69 \pm 2.44$ & 0.000 \\
\hline $\mathrm{B} \mathrm{mg} / \mathrm{kg}$ & $55.75 \pm 9.60^{\mathrm{a}}$ & $50.51 \pm 12.07^{\mathrm{a}}$ & $32.23 \pm 11.37^{\mathrm{b}}$ & $25.40 \pm 9.58^{\mathrm{b}}$ & $40.97 \pm 16.18$ & 0.001 \\
\hline $\mathrm{Ca} \mathrm{mg} / \mathrm{g}$ & $4.35 \pm 4.05$ & $3.33 \pm 1.07$ & $5.10 \pm 2.82$ & $1.16 \pm 1.07$ & $3.48 \pm 2.81$ & 0.130 \\
\hline $\mathrm{Cu} \mathrm{mg} / \mathrm{kg}$ & $47.09 \pm 22.5$ & $32.00 \pm 7.55$ & $36.41 \pm 6.77$ & $21.50 \pm 8.01$ & $34.25 \pm 15.18$ & 0.460 \\
\hline $\mathrm{Fe} \mathrm{mg} / \mathrm{kg}$ & $2.32 \pm 0.14^{\mathrm{a}}$ & $1.79 \pm 0.22^{\mathrm{b}}$ & $2.11 \pm 0.23^{\mathrm{a}}$ & $1.47 \pm 0.22^{\mathrm{b}}$ & $1.92 \pm 0.38$ & 0.000 \\
\hline $\mathrm{Mg} \mathrm{mg} / \mathrm{g}$ & $36.57 \pm 4.76^{\mathrm{a}}$ & $23.96 \pm 2.84^{\mathrm{b}}$ & $27.83 \pm 3.67^{\mathrm{a}}$ & $20.00 \pm 3.45^{\mathrm{c}}$ & $27.90 \pm 7.17$ & 0.000 \\
\hline $\mathrm{P} \mathrm{mg} / \mathrm{g}$ & $0.162 \pm 0.04^{\mathrm{a}}$ & $0.08 \pm 0.01^{\mathrm{c}}$ & $0.123 \pm 0.03^{\mathrm{b}}$ & $0.08 \pm 0.02^{\mathrm{c}}$ & $0.111 \pm 0.04$ & 0.000 \\
\hline $\mathrm{Zn} \mathrm{mg} / \mathrm{g}$ & $5.37 \pm 1.07^{\mathrm{a}}$ & $4.40 \pm 1.21^{\mathrm{a}}$ & $2.70 \pm 0.43^{\mathrm{b}}$ & $2.41 \pm 0.56^{\mathrm{b}}$ & $3.72 \pm 1.49$ & 0.000 \\
\hline $\mathrm{Mn} \mathrm{mg} / \mathrm{kg}$ & & & & & &
\end{tabular}

a,b,c: Aynı satırdaki farklı harfle gösterilen ortalamalar arasındaki fark önemlidir. Değerler ortalama \pm standart sapma olarak verilmiştir.

Yumurtacı tavuk rasyonlarına farklı seviyelerde $\mathrm{B}$ ilavesinin tibia mineral elementlerinden $\mathrm{B}, \mathrm{Ca}, \mathrm{Mg}$, $P, Z n$ ve $M n$ üzerine etkisi önemli $(P<0.01)$, $C u$ ve $\mathrm{Fe}$ üzerine etkisi ise önemsiz ( $P>0.05)$ bulunmuştur. Rasyona B ilavesi tibia B miktarını artırmış, $\mathrm{Ca}, \mathrm{Mg}, \mathrm{P}$, Zn ve Mn miktarını ise azaltmıştır.

\section{TARTIŞMA ve SONUÇ}

Hasarlı yumurta oranı ile ilgili olarak, Kurtoğlu ve ark. (16) ile Yeşilbağ ve Eren (15) yürütmüş oldukları çalışmalarında rasyona ilave edilen farklı seviyelerdeki B'nin yumurtacı tavuklarda hasarlı yumurta oranını benzer şekilde iyileştirdiğini $(P<0.01)$ bildirmiş olmalarına rağmen, Olgun ve ark. (19) yumurtacı tavuk rasyonlarına B ilavesinin hasarlı yumurta oranına etkisinin olmadığını, Eren ve ark.(8) ise rasyona $200 \mathrm{mg} / \mathrm{kg}$ ve üzeri B ilavesinin hasarlı yumurta oranını arttırdığını $(\mathrm{P}<0.01)$ tespit etmişlerdir.

Rasyona ilave edilen B'nin yumurtac tavukalarda hasarlı yumurta oranını değiştirmediğini veya olumsuz etkilediğini bildiren çalışmalarla mevcut çalışma arasındaki farklılıklar hayvanın yaşı, yumurtlama dönemi ve rasyona ilave edilen B'nin form ve seviyesinden kaynaklanmış olabilir.

Yumurta ağırlığı olarak elde edilen sonuçlar bazı araştırıcıların $(8,15)$ bulgularıyla paralellik gösterirken, birkısım araştırıcıların $(13,16,17,18)$ bildirişleyle farklılık arzetmektedir.

Yumurtaların normal şekil indeksine sahip olması pazarlama açısından büyük önem taşımaktadır. Aşırı uzun ya da toparlak yumurtaların pazarlama ve taşıma için yapılan paketlemede problemlere sebep olduğu bilinmektedir (11). 
Araştırma bulgularına göre şekil indeksi (\%) değerlerinin 74.14-76.22 arasında olması söz konusu değerlerin arzu edilen ve olması gereken sınırlar içerisinde yer aldığını göstermektedir. Olgun ve ark. (19), Sızmaz ve Yıldız (18) ve Eren ve ark. (8), da çalışmalarında B'nin yumurtacı tavuklarda şekil indeksi üzerine etkisini önemsiz bulmuşlardır.

B ilavesinin kabuk kırılma mukavemetine etkisinin araştırıldığı çalışmaların $(8,15,20)$ sonuçları ile mevcut araştırma bulguları arasında önemli ölçüde benzerlik bulunmaktadır. Rossi ve ark. (21), Olgun ve ark. (19), Olgun (20), Sızmaz ve Yıldız (18) ve Sızmaz ve ark. (22) rasyona B ilavesinin kabuk kalınlığını etkilemediğini, Grossu ve ark. (23) ise düşürdüğünü bildirmişlerdir.

B’nin yumurtacı tavuklarda kabuk kalınlığına etkisini çalışan bazı araştırıcılar $(8,19,22)$ da kabuk kalınlığının B'den etkilenmediğini tespit etmişlerdir. Ancak, Yeşilbağ ve Eren (15), yaşlı yumurtacı tavukların rasyonuna B ilavesinin kabuk kalınlığını olumsuz yönde etkilediğini bildirmişlerdir.

Serum mineral elementi ile ilgili önceki yıllarda yapılan çalışmaların $(20,24)$ sonuçları ile mevcut çalışmadan elde edilen bulgular uyumluluk göstermiştir. Demirörs (25) ise rasyona farklı seviyelerde B ilavesininin serum B seviyesini etkilemediğini bildirmiştir. Olgun (20) yumurtacı tavuklarda rasyona ilave edilen B'nin plazma $\mathrm{Cu}$ düzeylerini artırdığı sonucuna ulaşılmıştır. Şimşek (26), yaşlı yumurtacı tavukları farklı seviyelerde B içeren rasyonlarla besledikleri çalışmasında, B'nin serum Ca düzeylerini etkilemediğini ifade etmiştir (P>0.05). Öte yandan Kurtoğlu ve ark. (16) ve Yeşilbağ ve Eren (15) ise farklı seviye ve formdaki B'nin serum Ca düzeyini artırdığını bildirmişlerdir. Kurtoğlu ve ark. (16) ve Olgun (20), rasyona farklı seviye ve formlarda ilave edilen B'nin mevcut çalışmada elde edilen bulgularla benzer şekilde serum $\mathrm{Ca}$ düzeylerini azalttı̆̆ını tespit etmişlerdir. Kurtoğlu ve ark. (16), Demirörs (25) ve Şimşek (26), rasyona farklı seviye ve formda B ilavesinin söz konusu çalışmadan elde edilen sonuçlara benzer şekilde serum Mg düzeyini etkilemediğini belirtmişlerdir.
Yumurtacı tavuklarda $\mathrm{Mn}$ yetersizliği yumurta veriminde düşüşe, kabuksuz ya da ince kabuklu yumurta miktarında artışa yol açtığından bu konuda daha sağlıklı bir sonuca ulaşabilmek için rasyona ilave edilen B'nin serum, yumurta ve kemik $\mathrm{Mn}$ değerlerinin detaylı bir şekilde araştırılması gerektiği (27) belirtilmiştir. Demirörs (25) ve Olgun (20), farklı seviyelerde B içeren rasyonlarla beslenen yumurtacı tavuklarda Zn'nin muameleden etkilenmediğini bildirmişlerdir. Bazal rasyona B ilavesi serum Fe düzeyinin azalmasına neden olmuştur. Demirörs (25) B'nin plazma $\mathrm{Fe}$ düzeyini etkilemediğini ancak rakamsal olarak azalttığını bildirmiştir. Rasyona B ilavesi serum $\mathrm{Na}$ düzeyini $50 \mathrm{mg} / \mathrm{kg}$ B seviyesinde artırırken 75 ve $150 \mathrm{mg} / \mathrm{kg}$ B seviyelerinde azaltmıştır. Demirörs (25), rasyona B ilavesinin yumurtacı tavuklarda serum $\mathrm{Na}$ düzeyini değiştirmediğini bildirmiştir. Literatür verileri incelendiğinde plazma $\mathrm{Na}$ değerlerinde rakamsal azalmalar olduğu için bu yönüyle mevcut araştırma bulgularına benzer olduğu söylenebilir. Bazal rasyona B ilavesi serum $P$ düzeyini rakamsal olarak azaltmıştır. Criste ve ark. (28) da serum $P$ seviyesinin $B^{\prime}$ den etkilenmediğini mevcut araştırma bulgularına benzer şekilde bildirmişlerdir. Mevcut araştırma bulguları ile literatür çalışmaları arasındaki farklıııların rasyona ilave edilen B'nin kaynağı ve rasyondaki seviyesi, bazal rasyon mineral içeriği, deneme süresi ve araştırma şartlarının farklı olmasından kaynaklandığı düşünülmektedir.

Grossu ve ark. (23) 0, 25, 40 ve 90 ppm seviyelerinde $B$ içeren rasyonlarla beslenen yumurtacı tavuklarda, yumurta kabuğu Ca düzeylerini sırasıyla 25.11, 26.45, 25.48 ve 25.92 $\mathrm{g} / 100 \mathrm{~g}$ olarak tespit etmişlerdir. Rasyona farklı seviyelerde B ilavesinin mevcut araştırma bulgularında olduğu gibi yumurta kabuğu Ca düzeyini artırdığını bildirmişlerdir. Literatürde rasyona B ilavesinin yumurta kabuğu minerallerinden $\mathrm{Ca}$ hariç diğer minerallere $(B, F e, P, Z n, M g, M n, N a, P b$ ve $S)$ etkisinin incelendiği yerli ya da yabancı dilde yayınlanmış herhangi bir çalışmaya rastlanılmamıştır. 
Dolayısıyla söz konusu parametreleri karşılaştırmalı olarak tartışmak mümkün olmamıştır.

Yumurtacı tavuklarda, kabuk ve dışkı yoluyla olan Ca kayıplarının, Ca tüketimlerinden daha fazla olması durumunda negatif $\mathrm{Ca}$ bilançosu oluşur. Bu durumun telafisi rasyon Ca düzeyinden bağımsızdır ve bir başka ifade ile oluşan negatif Ca tablosu rasyona yüksek Ca ilavesi ile düzeltilemez $(1,29)$. Bu nedenle kabuk teşekkülü için ihtiyaç duyulan Ca'nın bir kısmı kemiklerden sağlanır. Yüksek verim sebebiyle kemiklerden mobilize edilen Ca tekrar yerine konulamazsa, kemikler zayıflar. Bunun sonucunda osteoporoz (30) ve kafes yorgunluğu denilen metabolik rahatsızlıkların görülme riski artar, yumurta verimi ve kabuk kalitesi düşer $(1,31)$. Bu dönemde yumurta tavuklarının Ca yetersizliğine karşı koyabilme kabiliyeti, onların iskelet Ca depolarının bir fonksiyonu olduğu için tavukların iskeletlerinde mümkün olduğunca fazla Ca depolamaları arzu edilir (1). Kalsiyum, P ve vitamin D'nin besleme bakımından kemik mineralizasyonunu etkileyen ana faktörler oldukları kabul edilmektedir. İz elementlerin kemik kalitesine olan direk etkisi yanında, bu iz elementlerin Ca tüketimine olan etkisiyle kemik kalitesine dolaylı bir etkisinin de olabileceği yönünde araştırma sonuçları mevcuttur $(13,18)$.

Kemiğin mekanik özellikleri, kemiğin fonksiyonel karakterleri ile diğer besinsel faktörlerin ilişkisini belirlemede kullanılabilmektedir $(32,33)$. Wilson ve Ruszler (13), kemik kırılma kuvveti ve kemik kül miktarının sıklıkla kemik kırılmalarını önlemede çeşitli rasyon ilavelerinin değerlendirilmesinde kriter olarak kullanılabileceğini, ancak iz elementlerin kemik mineralizasyonuna ve kırılma kuvvetine etkisinin daha az ilgi çektiğini bildirmişlerdir.

Yumurtacı tavuk rasyonlarına farklı seviyelerde ilave edilen B’nin kemiğin biyomekanik özelliklerinin tümüne etkisi önemsiz olmuştur. Wilson ve Ruszler (13), Mızrak ve Ceylan (24), Mızrak ve ark. (34), Sızmaz ve Yıldız (35) ve Demirörs (25) de yumurtacı tavuk ve piliç rasyonlarına farklı seviyelerde ilave B'nin kemik çapı, kemik duvarı kalınlığı, kemik stres, kesme kuvveti ve kesme enerjisini etkilemediğini bildirmişlerdir. Olgun (20), yumurtacı tavuklarda kemik çapı ve kesit alanının B'den etkilenmediğini, kemik duvar kalınlığı, kemik stresi, kesme kuvveti ve kesme enerjisinde ise önemli artışların olduğunu tespit etmiştir.

Rasyona B ilavesinin tibia Cu düzeyine etkisiyle ilgili bulgular Şimşek (26) ve Demirörs (25)'ün bildirişleriyle benzer olmuştur. Ancak, Olgun (20), rasyona farklı seviyelerde ilave edilen $\mathrm{B}^{\prime}$ nin tibia $\mathrm{Cu}$ düzeyini önemli derecede artırdığını bildirmiştir.

Rasyona B ilavesi gruplarda tibia Fe düzeyini etkilememiştir. Demirörs (25) ve Şimşek (26), rasyona farklı seviye ve formda ilave edilen B'nin mevcut çalışmada olduğu gibi kanatlı hayvanlarda tibia $\mathrm{Fe}$ düzeylerini etkilemediğini tespit etmişlerdir.

Şimşek (26) ve Olgun (20), kanatlı rasyonlarına farklı seviyelerde B ilavesinin mevcut araştırma bulgularında olduğu gibi tibia $\mathrm{Mg}$ değerlerini düşürdüğünü, Demirörs (25) ise B ilavesinin tibia $\mathrm{Mg}$ düzeyini etkilemediğini bildirmiştir.

Rasyona ilave edilen B'nin tibia $P$ düzeyini azalttığı gözlenmiştir. Wilson ve Ruszler (7) ve Olgun (20) da ilave B'nin mevcut çalışmada olduğu gibi tibia P düzeyini azalttığını bildirmişlerdir. Ancak, Mızrak ve ark (34) ve Wilson ve Ruszler (13) farklı seviyelerdeki $B^{\prime}$ nin tibia $P$ düzeyini değiştirmediğini; Mızrak ve Ceylan (24), Sızmaz ve Yıldız (35) ise B'nin tibia P düzeyini artırdığını belirtmişlerdir.

Bazal yemle beslenen grubun tibia $\mathrm{Zn}$ düzeyi diğer gruplardan daha yüksek olmuştur. Rasyona B ilavesinin kemik $\mathrm{Zn}$ düzeyine etkisinin araştırıldığı $(16,25,26)$ çalışma sonuçları ile mevcut araştırma bulguları uyum göstermektedir. Fakat Olgun (20), yumurtacı tavuk rasyonlarına B ilavesinin tibia Zn düzeyini artırdığını bildirmiştir.

Bazal ve $50 \mathrm{mg} / \mathrm{kg}$ B ilaveli rasyonlarla beslenen grupların tibia $\mathrm{Mn}$ düzeyi diğer gruplardan daha yüksek olmuştur. Demirörs (25) B ilavesinin tibia Mn düzeyini düşürdüğünü, Şimşek (26) ise $M n$ düzeyininin $B^{\prime}$ den etkilenmediğini bildirmiştir.

Sonuç olarak, kanatlılarda B'nin mineral dengesi ve metabolizması üzerinde pozitif yönde önemli 
biyolojik etkiye sahip olduğu düşünülerek yumurtlamanın son döneminde bulunan yumurtacı tavukların rasyonuna yumurta dış kalite özelliklerini, özellikle de kırılma mukavemetini iyileştirmek için 50 $\mathrm{mg} / \mathrm{kg}$ B ilavesinin yeterli ve önerilebilir olacağı kanaatine varılmıştır. Ayrıca bor içeriği yüksek yemlerin hayvan sağlığı üzerine etkilerine bakılırken, insan sağlığı üzerine de etkilerinin araştırılması gerekliliği tavsiye edilmektedir (36). Borun yumurtacı tavuklarda etkinliğinin daha iyi incelenmesi amacıyla yeni bilimsel çalışmaların yapılması gerekmektedir (37).

\section{KAYNAKLAR}

1. Keshavarz K., 1987. Influence of feeding a high calcium diet for various durations in prelaying period on growth and subsequent performance of white leghorn pullets. Poultry Sci, 66, 15761582.

2. Polat C., Kaydı H. D., Koç, F., 1999. Türkiye'de kanatlı yemlerinde katkı maddeleri, yağ kullanım durumlarının saptanması üzerine bir araştırma. Uluslararası Hayvancılık'99 Kongresi, 21-24 Eylül, İzmir.

3. NRC., 1984. National Research Council: Nutrient Requirements of Poultry, $8^{\text {th }}$ ed. Subcommittee on Poultry Nutrition. National Academy Press, Washington DC., 11-13.

4. Nielsen F.H., 1997. Boron in human and animal nutrition. Plant and Soil, 193, 199-208.

5. Eren M., 2004. Bor'un biyolojik önemi ve metabolizma üzerine etkileri. Erciyes Üniv Vet Fak Derg, 1, 55-59.

6. Hunt CD., Herbel JL., 1992. Boron affects energy metabolism in the streptozotocin-injected, vitamin D3-deprived rat. Magnesium Trace Elem, 10, 374-386.

7. Wilson JH., Ruszler PL., 1998. Long term effect of boron on layer bone strength and production parameters. Brit Poultry Sci, 39, 11-15.

8. Eren M., Uyanık F., Kucukersan S., 2004. The influence of dietary boron supplementation on egg quality and serum calcium, inorganic phosphorus, magnesium levels and alkaline phosphatase activity in laying hens. Res Vet SCl, 6, 203-210.

9. AOAC., 1990. Official methods of analysis. Vol.1. $15^{\text {th }}$ ed. Assoc. Off. Anal. Chem., Arlington, VA.

10. Mertens D., 2005. AOAC Official Method 975.03. Metal in Plants and Pet Foods. Official Methods of Analysis, $18^{\text {th }}$ edit. Horwitz, W., and G.W. Latimer, (Eds). Chapter 3, pp 3-4, AOACInternational Suite 500, 481. North Frederick Avenue, Gaitherburg, Maryland 20877-2417, USA.

11. Çelebi Ş., Macit M., 2003. Yumurtacı tavuk rasyonlarına geç dönemde hayvansal ve bitkisel yağ ilavesinin performans, yumurta kalitesi ve yumurta sarısı yağ asidi kompozisyonu üzerine etkileri. II. Ulusal Hayvan Besleme Kongresi, 1820 Eylül, 2003, 94-98, Konya.

12. ASAE Standarts, 2003. Shear and three-point bending test of animal bone. ANSI/ASAE S459 DEC01, USA.

13. Wilson JH., Ruszler PL., 1996. Effects of dietary boron supplementation on laying hens. Brit Poultry Sci, 37, 723-729.

14. SAS., 1996. SAS Institute Inc., NC, USA

15. Yeşilbağ D., Eren M., 2008. Effects of dietary boric acid supplementation on performance, eggshell quality and some serum parameters in aged laying hens. Turk J Vet Anim Sci, 32, 113-117.

16. Kurtoğlu V., Kurtoğlu F., Coşkun B., Şeker E., Balevi T., Çetingül IS., 2002. Effects of boron supplementation on performance and some serum biochemical parameters in laying hens. Rev Med Vet-TOULOUSE, 153, 823-828.

17. Hakan KB., Gultekin Y., Özge S., 2012. Effects of boric acid and humate supplementation on performance and egg quality parameters of laying hens. Rev Bras Cienc Avicola, 14, 283-289.

18. Sizmaz O., Yildiz G., 2016. Influence of dietary boric acid and ascorbic acid on performance, egg traits, cholesterol and bone parameters of laying hens. Ankara Üniv Vet Fak Derg, 63, 151-156.

19. Olgun O., Cufadar Y., Yıldız AÖ., 2009. Effect of boron supplementation fed with low calcium to 
diet on performance and egg quality in molted laying hens. J Anim Vet Adv, 8, 650-654.

20. Olgun O., 2011. Yumurtacı tavuk rasyonlarına farklı seviyelerde ilave edilen bor ve bakırın performans, yumurta kabuk kalitesi, yumurta sarısı kolesterolü ve kemiğin biyomekanik özelliklerine etkisi. Doktora Tezi, Selçuk Üniv. Fen Bil. Enst., Konya.

21. Rossi A. F., Miles R. D., Bootwalla S. M., Wilson H. R., Eldred A. R., 1993. The effect of feeding two sources of boron on broiler breeder performance. Poultry Sci, 72, 1931-1934.

22. Sızmaz Ö., Yıldız G., Köksal BH., 2014. Effects of Single or Combined Dietary Supplementation of Boric acid and Plant Extract Mixture on Egg Production, Egg Quality and Blood Cholesterolemia in Laying Hens. Kafkas Univ Vet Fak Derg, 20, 599-604.

23. Grossu DV., Criste RD., Score R., Duca R., Ciurascu C., 2005. Effect of the supplemental PROLINBOR, boron and linolenic acid-enriched protein concentrate, added to layer diets on egg quality. European Symposium on the Quality of Eggs and Egg Products. 23-26 May 2005, 113-118, Doorwerth, The Netherlands.

24. Mızrak C., Ceylan M., 2009. Damızlık yumurtacı tavuk yemlerine farklı seviye ve formda bor ilavesinin performans, kemik gelişimi ve bazı kan parametreleri üzerine etkisi 6.Ulusal Zootekni Bilim Kong., 60-69, 24-26 Haziran, Erzurum.

25. Demirörs G., 2007. Yumurtacl piliçlerde yumurtlama öncesi dönemde farklı seviyelerde kalsiyum ve bor içeren rasyonların büyüme, kemik mineralizasyonu, bazı serum parametreleri ve yumurtlama dönemi performans ve yumurta kabuk kalitesine etkileri.Yüksek Lisans Tezi, Selçuk Üniversitesi Fen Bilimleri Enstitüsü, Konya.

26. Şimşek M., 2011. Etlik piliç rasyonlarına bor (ortoborik asit) ilavesinin performans değerleri ile tibia mineral konsantrasyonu ve bazı kan parametreleri üzerine etkisi. Yüksek Lisans Tezi, Atatürk Üniv. Fen Bilimleri Enst. Erzurum.

27. Okuyan MR., 1997. Hayvan Besleme Biyokimyası, Ankara Üniv Ziraat Fak Yayın no: 1491, Ders kitabı:
450, 350 s, Ankara.

28. Criste RD., Grossu DV., Ciurascu C., Scorei R., Mihut M., 2005. Investigations on the effect of the supplemental Vetabor, boron Enriched protein concentrate, added to broiler diets on breast meat fatty acids profile- XVII European Symposium on the Quality of poultry Meat and the XI European Symposium on the Quality of Eggs and Egg Product, 23-26 May 2005, p. 165169, Doorwerth, The Netherland.

29. Hurtwitz S., Griminger P., 1960. Observation on the calcium balance of laying hens. J Agr Sci, 54, 373-377.

30. Whitehead CC., 2004. Overview of bone biology in the egg-laying hen. Poultry Sci, 83, 193-1999.

31. Scott ML., Neisheim MC., Young RS., 1982. Nutrition of the chicken. $3^{\text {rd }}$ ed., M.C. Scott and Associates, Ithaca, New York, 782-789.

32. Nimmo RD., Peo ER., Moser BD., Cunningham PJ., Olson DG., Crenshaw TD., 1980. Effect of various levels of dietary calcium and phosphorus on performance, blood and bone parameters in growing boars. J Anim Sci, 51, 100-111.

33. Thomas ML., Ibarra MJ., Solcher B., Wetzel S., Simmons DJ., 1988. The effect of low dietary calcium and calcium supplementation on calcium metabolism and bone in the immature, growing rat. Bone Miner, 4, 73-82.

34. Mızrak C., Yenice E., Can M., Yıldırım U., Atik Z., 2010. Effect of dietary boron on performance, egg production, egg quality and some bone parameters in layer hens. S Afr J Anim Sci, 40, 257264.

35. Sızmaz Ö., Yıldız G., 2014. Effects of dietary boric acid and ascorbic acid supplementation on performance, some blood and bone parameters in broilers. Kafkas Univ Vet Fak Derg, 20, 65-71.

36. Bintaş E., Özdoğan M., 2017. Bor ve zeolit içeren yemlerin yaşlı yumurtacı tavuklar üzerine etkileri. JOTAF, 14, 101-109.

37. Bozkurt M., Küçükyılmaz K., 2015. The role of boron in poultry nutrition Part II: Compositional and mechanical properties of bone and egg quality. World Poultry Sci J, 71, 483-492. 